\title{
Examining Jakarta office mosques: Islamic teaching practices and views of Islamic ideological issues ${ }^{1}$
}

\author{
Ridwan al-Makassary
}

Humanities Faculty at University of Science and Technology(USTJ)

Jayapura, Papua, Researcher of Peace NGO, Papua Peace and Development Action (PaPeDA) Institute

E-mail:almakassary@yahoo.com

\begin{abstract}
This paper discusses Islamic teaching practices and perceptions of mosque stakeholders concerning the ideological issues of: a democratic system of government versus formal implementation of Islamic sharia; gender equality; jihad, and pluralism in the Jakarta office mosques. After describing the research findings, the paper concludes that the phenomenon of neo-fundamentalism (in Olivier Roy's words) is growing and developing in office mosques. This can be seen in the dominance of literal and scripturalist Islamic interpretations, the importance given to implementing Islamic sharia and the rejection of democracy, a hatred of Jews and Christians and the emergence of Muslim youth actors in Islamic neo-funda-
\end{abstract}

\footnotetext{
${ }^{1}$ This article is part of research findings of my research for "Research Fellowship Program 2010 of Asian Muslim Action Network (AMAN), Bangkok Thailand". Research into this sensitive issue would not have been possible without the warm welcome extended by the managers of the office mosques studied. Although their views tended to be more radical than mine, I found them to be devoutly religious people. I greatly appreciate their sincerity and the warmth of their fellowship. The same appreciation is due to all parties that supported me in doing this research, as well as the informants whose names could not be mentioned for their safety.
} 
mentalism. Other findings concern the influence of the Tarbiyah movement, an offshoot of the Ikhwanul Muslimin (Muslim Brotherhood), which is being felt in the office mosques studied. Learning about Islamist understandings will allow us to check its development, which may destroy the friendly, peaceful face of Islam.

Paper ini mendiskusikan praktik pengajaran Islam dan persepsi pemangku kepentingan masjid berkaitan dengan isu-isu ideologis: sebuah sistem pemerintahan demokratik versus implementasi formal syari'at Islam; kesetaraan jender; jihad, dan pluralism di masjid perkantoran Jakarta. Setelah deskripsi temuan penelitian, paper ini menyimpulkan bahwa fenomena neofundamentalisme (meminjam Olivier Roy) sedang tumbuh dan berkembang di masjid-masjid perkantoran. Ini terlihat dari dominannya intepretasi skriptural dan literal, pentingnya menerima pelaksanaan formal syari'at Islam, kebencian terhadap Yahudi dan Kristen dan kebangkitan aktor-aktor muda fundamentalisme Islam. Temuan lain terkait dengan gerakan Tarbiyah, sebuah anak ideologi Ikhwanul Muslimin (Muslim Brotherhood), yang cukup kental ditemukan di masjid yang diteliti. Mengkaji pemahaman Islam akan memungkinkan kita mengawasi perkembangannya, yang mungkin menghancurkan wajah Islam yang ramah dan damai.

Keywords: Office mosque; Islamic teaching; Democracy; Jihad; Gender equality; Pluralism

\section{Introduction}

Indonesia has witnessed many significant changes, especially religious radicalization following the collapse of Soeharto regime. This can be seen through the fact that the Indonesian political atmosphere in the post-New Order has been signaled by the euphoria of democracy and the liberalization of politics. ${ }^{2}$ Such liberalization has allowed some radical Islamic groups, which were in dormant during the New Order era, to come alive to echo their voices and ideologies.

\footnotetext{
2Bachtiar Effendi, "Enforcement of Shari'ah in Indonesia: Challenges and Prospects" in: Islam and Democracy, Singapore: Konrad-Adenauer-Stiftung Singapore, 2004, 75.
} 
Basically, this extreme Islamic movement has been deeply cradled by Middle Eastern ideologies which they believe to be the authentic ones. In terms of religious thoughts, they are influenced by radical Salafism and Wahabism. This radical movement aims at the establishment of a single universal Islamic Caliphate for the world's Muslims. ${ }^{3}$ Therefore, the ideology that stimulates this group seems to be Islamic teachings that legitimatize all types of their movements and activities; such an ideology becomes the motivation and direction through which this group develops. It can be said that their ultimate project is to Islamize all humankind.

According to Greg Fealy ${ }^{4}$, radical Islamic groups in Indonesia can be divided into four types; (1) political, educational and intellectual (2) vigilante, being community groups formed to prevent wrongdoing and immorality, particularly those which law enforcement agencies are not concerned with, and (3) paramilitary; (4) terrorists. The first category comprises groups which do not use violence in their efforts for radical Islamic change, such as Hizbut Tahrir in Indonesia. In the vigilante category is the Front Pembela Islam (FPI - Islamic Defenders Front) and the paramilitary group includes Laskar Jihad Forum Komunikasi Ahlus Sunnah wal Jama'ah (LJ FKAWJ). Terrorists are those who use violence in the name of religion.

Generally speaking, the emergence of the radical Islamic movement does not have any connection whatsoever to other Indonesian Islamic mass organizations, like Muhammadiyah and Nahdlatul Ulama which are known as the mainstream of Islam in the Archipelago. Robert $\mathrm{W}$. Hefner is of the opinion that moderate Islamic communities

\footnotetext{
${ }^{3}$ Azyumardi Azra, "Islam in Southeast Asia: Tolerance and Radicalism", paper presented at the Mieguyah Public Lecture, the University of Melbourne, Wednesday 6 April, 2005.

${ }^{4}$ Greg Fealy, Local Jihad: Radical Islam and Terrorism in Indonesia, Australia: ASPI, 2005, 13.
} 
remain the majority in Indonesia compared to their counterparts of radical Islamic supporters. However, the moderate communities are not well organized and structured. ${ }^{5}$

In a later development, the Islamic radical movement has implanted its ideology in mosques that are commonly under the auspices of the two biggest Islamic organizations: Nahdhatul Ulama and Muhammadiyah. In this light, the general chairman of NU, Hasyim Muzadi, has warned all Moslim communities to be fully vigilant in regard to the emergence of what has been called transnational ideology. For him, such an ideology is at odds with Indonesian mainstream Islam, which has been renowned for its tolerant and moderate character. Hence, this ideology must be rejected. ${ }^{6}$

Moreover, the Central Committee of NU saw it as necessary to protect NU's mosques from the inflitration of the radical movement. In October 2007, at Pondok Pesantren (Islamic boarding school) Zainul Hasan Genggong, Probolinggo, East Java, the NU central committee held a Bahtsul Masa'il (discussion on contemporary issues) which issued an edict on the certification of NU's mosques in order to keep them safe from the influence of and possible takeover by this movement. Similarly, the Central Chair of Muhammadiyah also issued a decree No.149/December 2006 that aims to protect Muhammadiyah's properties, such as mosques, schools, orphanages, hospitals, and universities from the influence and takeover by this radical group, whose world-view is very different from that of Muhammadiyah.

${ }^{5}$ Robert W. Hefner, "Political Islam in Southeast Asia: Assessing the Trends" (keynote Address), in conference Political Islam in Southeast Asia, 25 March 2003, Washington DC.

6"PBNU Desak Pemerintah Cegah Ideologi Transnasional"(PBNU demands the Indonesian Government to prevent transnational ideology), See www.nu.or.id, last accessed 9 February 2009 Time 13.20. 


\section{Research methods}

This research employed qualitative methods to describe the phenomenon. The qualitative methodology used in this research was library research, field study (in-depth interview) and participatory observation. The library research provided a theoretical framework for the issue. The field study collected the data needed. The data collection tools were in-depth interviews following structured guidelines. In addition to this, participant observation was employed to gather data in a systematic and unobtrusive way, and to enrich the analysis.

\section{The small narratives of the mosques studied}

With great enthusiasm, the mosque preacher for this Friday afternoon said that "the real terrorists are the Jews and the Christians". The main content of his sermon was dedicated to name-calling and mockery of these two Abrahamic religions. To legitimize his sermon the preacher frequently cited and misquoted verses from the Koran, among them the ones saying, "The Jews and Christians will not be content until you (Muslims) follow their religions." Another was, "For Allah, the most exalted religion is Islam." 7

This sermon provoked considerable anxiety in the writer; what are the actual Islamic teaching practices used in office mosques, and does this religious teaching proclaim and appeal to the values of Islamic neofundamentalism? These questions guided the writer in looking into Islamic religious teaching practices in the two anonymous office mosques. However, in enriching the study, the author was observing several office mosques located in Jakarta.

7Observed by the writer at a Jakarta office mosque, July 2010 . 


\section{A history of office mosques in Jakarta}

Before starting this research, the writer had already been to Friday worship in office mosques in Jakarta. The mosque congregations, who were mostly white-collar workers, seemed to take part enthusiastically. It appeared that the congregation comprised not only these office workers, but also visitors from outside and people who had business in these offices. Worship and other activities, such as religious study and discussion groups and the communal five daily prayers, had apparently become or were becoming routine activities for a section of the Muslim office-worker personnel.

These days almost all offices, spread right across greater Jakarta, have mosques. If we look at this more closely, the industrial and trading belt of the MT Haryono, Gatot Subroto, Semanggi, Kuningan and Sudirman areas, for example, are full of mosques and prayer rooms. According to one informant, Jakarta's office mosques number in the hundreds. This number may even be in the thousands if mosques outside greater Jakarta are included. ${ }^{8}$ There is reliable data showing that 250 office mosques have combined in FORSIMPTA (Forum Silaturahmi Masjid Perkantoran/The Networking Forum of Office Mosques). ${ }^{9}$

FORSIMPTA was basically established to strengthen the bonds of mutual fellowship (silaturahmi), and to shape office mosques as centers of religious education for the Muslim professional community. The first working meeting, which became the foundation of FORSIMPTA's creation, was attended by ten representatives of office mosques, prayer rooms and women's Islamic study groups in the Gatot Subrato and Sudirman area on 18 - 20 May 2001, at Wisma Mandiri, Ciawi and West Java.

8Interview with C, July 2010, in the offices.

${ }^{9}$ http://forsimpta.multiply.com/, last accessed 25 August 2010. 
On 9 June 2001 (7 Rabi'ul Akhir 1422H), at Jakarta's Plaza Mandiri Mosque, the formation of a Jakarta-wide office mosque forum was declared by 14 founders, representing mosques, prayer rooms and women's Islamic study groups in the Gatot Subrato and Sudirman area. The 14 foundation members were: (from the Gatot Subroto area) the Al-Muhajirin Mosque - Graha Unilever; the Plaza Mandiri Mosque; the Telkom Mosque; the LIPI Mosque; the Al Maghfiroh Jamsostek Mosque; Dirjen Pajak (taxation office) Mosque; Gedung Menara Mulia prayer room; Surveyor Indonesia prayer room, and from the Sudirman area the Miftahul Jannah PT Gulf Indonesia Prayer Room; the Plaza Bapindo Prayer Room; the Al'Alaa BEJ Mosque, the Itjen Depdiknas (education office) Mosque and the Land Mark Mosque.

Overall, based on initial information from FORSIMPTA website, religious activities in office mosques are blooming, from daily prayers, religious study groups, education, mobilizing zakat (charitable donation) funds, faith training and executive prayer retreats, through to activities during Ramadan, (the fasting month). In short, office mosques are able to satisfy spiritual longings; in the midst of the hustle and bustle of daily life they provide a place for spiritual catharsis and relief from the high stress levels felt by these Muslim office workers.

In their shape and form these office mosques show great variation. Some take the usually form of mosques, with their own building complete with a dome, minaret and permanent, purpose-built space. Examples of these are the al-Ihsan Mosque of the Capital Investment Co-ordination Body (BKPM) and the mosque of Kementrian Pekerjaan Umum (the Ministry of Public Works). However there are also mosques consisting of only one large (or even small) room, on one floor of an often multi-storey office building. For example, the mosque of the Ministry of Public Housing (Kemenpera) is on the second floor, and is 
spacious enough to accommodate its congregation numbering in the hundreds. On the other hand, some office basement car parks are converted into mosques on Fridays. After prayers they revert to their function as parking areas. There are also mosques in office auditoriums or meeting rooms, which are borrowed to function as mosques every Friday.

The reasons for establishing office mosques are very diverse. ${ }^{10}$ Firstly there are mosques established at the volition of an office's Muslim community, who want a mosque so they can conduct communal worship. Secondly, some mosques are established by the office management, factoring in the efficiency of personnel going to Friday worship in an office mosque and thus reducing the effective loss of working time. Thirdly, office management could take a political approach, particularly in the years 1980 - 2000 when there were only three political parties; Golkar (the Functional Group) with its yellow flag, PPP (United Development Party) with a green flag, and PDI (Indonesian Democracy Party). Jakarta was almost if not completely 'greened' by PPP. Golkar, noted as the party of the Government, worked to defeat PPP in the Jakarta region with three strategies; firstly by building mosques in every office complex, secondly by working to have every employee join a congregation for Friday worship, especially in offices, and thirdly by screening preachers and sermon material so they did not conflict with official policy, or oppose or damage those in power.

In Muslim offices, attendance at the office mosque may be seen as influenced by the religious faith of the manager. One senior official and informant at the Capital Investment Co-ordination Body ${ }^{11}$ said that if a

${ }^{10}$ Interview with KY, 30 July 2010.

${ }^{11}$ Informal discussion with an official and informant at the mosque, after midday (zuhur) prayers, July 2010. 
non-Muslim became manager, then the religious activities which flourished were those of that manager's religion. In the situation where the manager was Muslim, those staff most dedicated to spiritual activities usually tried to use the opportunity for the glory of Islam. The writer formed the opinion that there remains a sort of veiled competition between the followers of different religions in the way they demonstrably observe and display their religious activities. Moreover, this can produce fragmentation between office workers of different religions.

\section{Mosque congregation, preacher and mosque managers: a brief profile}

Generally speaking, the members of congregation who routinely take part in the mosque's religious activities are Muslim office staff. As well as this, a small part of the congregation comes from outside. All of the mosque managers come from within the offices with which it is connected. However at the mosques studied, some of the managers are retirees from the office.

The mosque managers most usually have a national (public) tertiary institution educational background, especially from the general faculties, and few of them have had any contact with Islamic studies. One influential manager of the mosque is a graduate of one of the country's leading universities, and completed further studies in Japan. The manager referred to, while not being recognized as a supporter of the party, has a wide network within the one Islamic political party, which is strongly Islamic-influenced. Informal discussions and researcher observations of internal mosque manager meetings gave hints of this. The congregation and managers can be said to have adequate financial means, as they comprise white-collar staff with good incomes. Interviews showed that the political affiliations or orientations of the 
congregation and managers tend towards the Islamic political parties which strive for the establishment of Islamic sharia law.

Still based on the researcher's interviews and observations, some preachers with responsibilities at the two mosques have a background in religious organizations, among them NU and Muhammadiyah. Both these Islamic organizations represent moderate Islam. Thus the religious studies and sermons they deliver consistently contain moderate elements. However there are also preachers who come from certain organizations and Islamic political party with significantly heavier Islamic overtones.

\section{Islamic teaching practices}

\section{Types of activities and their intensity}

The following section will set out the various routine religious activities held by the two mosques studied. In the opinion of the writer, to some extent the religious activities at these two mosques also occur in a similar form in other office mosques, and also generally in mosques throughout the country.

\section{The five daily prayers (rawatib)}

Mosques wherever, including in Indonesia, are generally dedicated places of ritual, namely for the five daily individual prayers and the communal Friday prayers. Both mosques studied are also used for these needs. However, if most big mosques always have crowds of worshipers for the five daily prayers, in these two mosques sizeable numbers of worshipers are only seen for the midday (Dzuhur) and late afternoon (Ashar) prayers, and for Friday worship. This is because these mosques in fact cater for office workers with working hours from morning until late afternoon, hours which encompass the Dzuhur and Ashar prayer times. 
At these two mosques the number of worshippers for Dzuhur and Ashar can reach 150 . Particularly at the first mosque studied, the five daily prayers are not limited the Dzuhur and Ashar. According to the manager of the second mosque studied, every work day there can be up to 60 people at Sunset (Maghrib) prayers, because some workers do not go home as soon as working hours are over. Some of them do overtime, and some delay going home to avoid the traffic jams which often occur in Jakarta. However for Isya prayers (at around $8.00 \mathrm{pm}$ ) there are approximately 50 people, and only 8 to 10 for dawn Shubuh prayers.

\section{Friday prayer}

Not all the mosques and prayer rooms in office buildings are used for Friday prayers, however the mosques studied are among those where Friday prayers are regularly conducted. Not surprisingly, every Friday at midday hundreds of staff crowd onto the escalators to go down to the mosque for Friday prayers. The congregation for Friday prayers comes not only from the office; many of them are from office buildings in the vicinity of the office. Going into the building at Friday prayer time, many (male) workers other than staff can be seen entering and queuing in the lobby for ID cards, and then heading down to the mosque located in the basement. The 200 visitor ID cards available in the lobby usually run out in the approach to Friday prayers. ${ }^{12}$ At the first mosque both office staff and visitors are free to come into the mosque for Friday prayers without having to queue for ID cards.

The Friday sermon at both mosques is delivered by a preacher invited by mosque. From the writer's observations, a different preacher delivers the sermon every Friday, and this is consistent with the mosque

${ }^{12}$ Interview with $A L, 20$ August 2010. 
manager's explanation that the schedule of preachers is determined in advance. ${ }^{13}$ The content of the sermon is left to the discretion of the preacher.

The subject material delivered through the sermon is general in nature. Some of the topics have concerned the meaning of justice for human life, time use and religious conviction, the laws of Allah SWT and raising religious devotion, elucidating chapters (surat) of the Koran, such as the surat al-Ashr and surat al-Zalzalah, verses 7 and 8. Apart from sermon material with a moderate content, some Friday sermons convey the religious understandings of Islamist groups. For example, there were sermons about the moral degeneration of Jews and Christians, and about America and Israel as truly terrorist nations. ${ }^{14}$

\section{Ramadan activities}

Ramadan activities at the two mosques are usually consolidated with various other activities, such as ritual spiritual cleansing when midday (dzuhur) and afternoon (ashar) prayers are observed, otherwise regular religious studies continue as normal. As well as this, there is a communal fast-breaking gathering for those who stay to observe sunset prayers (maghrib) together. During Ramadan the mosque provides 200 portions of takjil - a sweet food traditionally eaten to break the fast - and these are usually quickly and enthusiastically consumed by the people breaking their fast at the end of the day. ${ }^{15}$

\section{Charitable support activities for orphans and the victims of disasters}

Support for orphans is a social service activity conducted by the Zakat and Infak (philanthropic donations) section of the office's BAPEKIS

\footnotetext{
${ }^{13}$ Interview with $A D, 13$ July 2010.

${ }^{14}$ Observation from participating in Friday prayers at the office mosque under study..

${ }^{15}$ Interview with $A D, 13$ Julu 2010.
} 
(Body for Fostering Islamic Spirituality). Support money is taken from the charitable donations (ZIS) fund, and donations to this are deducted from staff salaries. The second mosque is quite active in helping natural disaster victims, for example those in various parts of Jakarta.

\section{Religious study groups}

Apart from Friday prayers, the most common mosque activity is religious study groups. Several kinds of these are part of the mosque routine, and these are discussed below.

1. Religious Studies following Midday Prayer (Dzuhur). These studies take place regularly every Tuesday and Friday. They are aimed at office staff and the general public. According to the manager of the second mosque studied, the person delivering them is usually from inside mosque circles. Outside speakers can propose themselves to lead this study, however on certain days there is a regular study speaker. I observed one religious leader named D. who graduated in Egypt, explains with great enthusiasm the excellence of Islam and the weaknesses of other religions. He spoke with great pride about some priests who had embraced Islam. Generally, however, not all speakers were like the religious leader D. Some of them more often gave commentaries on what being ethical is according to Islam.

2. Regular Evening Study every Monday. According to the mosque manager of the first mosque studied, these studies are to facilitate mosque members/ staff who want to learn reading the Koran, or improve their reading. The study group is intended for both male and female staff.

3. Regular Midday Study every Tuesday. Regular midday study every Tuesday is only for female members of the congregation. The mosque manager of the first mosque studied said that this takes 
place after the congregation's midday dzuhur prayers. Its venue is the women's rows of the mosque, an area about $8 \times 6$ meters, directly behind the men's rows. The study group participants are usually female personnel who take the opportunity in the break from office work to listen to spiritually cleansing words after midday prayers. Study group participants normally number from 40 to 60 people.

The material used is normally an exegesis of the Koran and Hadith. Each session usually takes from five to seven verses of the Koran and studies their meaning and interpretation. When the researcher joined this group the verses discussed were from Juz 29, Surat Al-Mursalat. Discussion of this chapter was targeted to end in the approach to the month of Ramadan.

The teaching method used for this study was a lecture. Usually each participant had a copy of the Koran, and opened it at the chapter/verse for discussion. The group manager also distributed a small booklet to each person, which addressed the text under discussion. The teacher explained the meaning and interpretation of the text verse by verse, and then went into this more deeply by presenting various actual issues related to the text. From time to time participants would ask questions or respond directly to the teacher's discussion if they did not fully understand, or wanted to know more about the commentary given. At the end of the analysis the teacher usually opened the topic for general discussion. These gatherings normally ended towards 1.00 p.m., when office work starts again.

The presence of the religious leader in these study sessions was not only to teach the Islamic material, but also to create a space where personal issues could be discussed, or where study group members could express their feelings. This usually happened 
after the session finished, and was done individually. These members often felt close to the religious leader, and were usually themselves the managers of women's study groups who were used to communicating with him.

4. Midday Studies on Wednesdays. This study is for male and female members of the congregation, and takes place after midday prayers (dzuhur). A different lecture is presented every week. The name of the speaker is normally decided in advance, on an annual schedule, although if a scheduled lecturer is unable to attend he is replaced by a substitute.

The mosque manager does not involve himself in selection of the material to be presented for study. ${ }^{16} \mathrm{He}$ only provides initial guidelines, so that the material is not too rigorous or radical, does not offend issues of ethnicity, race or intergroup relations, takes into account the mixture of people in the congregation, and does not create conflict which may later impact on the work performance of the company's staff. Based on information given to the researcher by the mosque manager and congregation, a variety of themes are used for study, ranging from commentary, the Hadith and Islamic law, to community issues.

On one occasion when the researcher was part of the study group, the speaker also discussed a celebrity case that was currently in the news. As well as making the study situation flow more easily, the case was used as an example of the topic presented. This session also discussed issues about the jilbab (women's head covering). ${ }^{17}$

${ }^{16}$ Interview with $A D$, mosque manager, 13 July 2010.

${ }^{17}$ Statements from the congregation, interview with $Y$, a regular member of the congregation (female) on 14 July 2010. 
In this study session, time did not allow room for discussion or questions and answers. As well as this, on several occasions when the researcher was making observations, the speaker was often in a hurry to leave the mosque for other business.

A considerable number of the congregation came to these study sessions. Almost the entire congregation took part in the midday gatherings. The space in the mosque measures about $10 \times 15$ meters, and it was usually filled with study group participants.

\section{Study materials}

The Islamic study material usually revolved around commentary, the Hadith, law and responses to current affairs. As touched on above, the speaker or preacher is usually given the freedom to present any material that is not ethnically/racially offensive and is not too rigorous. Thus in using literature, the book referred to is usually made available to each person by the speaker. He generally addressed only the core issues of the books used. Apart from this, the sessions were also conditioned by the limited time its participants had to follow intensive studies.

\section{Funds}

The managers of both mosques advised that the operational funds for the mosques came entirely from donations (infak and sedekah), both from the collection box provided by the mosque and from collections at Friday prayers. Particularly at the second mosque studied there are some frequent contributors, including managers from the office, who donate such things as carpets and prayer mats as well as money. Receipts and payments are usually reported when announcements are made after Friday prayers. 


\section{Criteria for religious teachers}

The mosque managers said that there are no special criteria for who should fill the positions of teacher or preacher at the mosque. The main thing is that they are considered to have expert religious knowledge. Neither of the mosque managers was greatly concerned about the proselytizer's background or organization, be it Muhammadiyah or NU. One mosque manager of the second mosque studied said that the preacher/speaker was in fact selected by the senior mosque manager. However a manager could propose a preacher to be given the opportunity to speak in front of the congregation. If the congregation seemed to like the content of the sermon, the preacher would be invited to preach again, or head the next study group. ${ }^{18}$

The writer's direct observations by joining Friday prayer study groups showed that those preachers/teachers whose orientation was somewhat towards Islamism were called upon most frequently. Once it was proposed to invite a speaker from the Liberal Islam Network (Jaringan Islam Liberal - JIL), however this was strongly opposed by another of the mosque's managers, because according to the senior manager, that "the mosque manager of the first mosque studied is really quite a fanatic." ${ }^{\prime 19}$

A number of fairly well known people have regularly and actively filled the positions of study group speaker and mosque preacher. Among these are Dr. Usman Assegaf, Dr. Uthman Umar Shihab, Dr. Didin Hafiduddin, and K.H. Arifin Ilham, who was well known before this for gracing television screens. ${ }^{20}$ Arifin Ilham was in fact scheduled as a regular study group leader every Wednesday midday at the first mosque

\footnotetext{
${ }^{18}$ Interview with SAJ, 17 July 2010.

${ }^{19}$ Interview with $A D, 13$ July 2010.

20Interview with A, 13 July 2010.
} 
studied. However, because their commitments were steadily increasing, such as overseas travel and religious community development, eventually they were seldom available for preaching or teaching at the first Mosque studied. The mosque managers apparently looked for replacements whose profiles were similar to these peoples, although they were not directly recognized by the senior mosque manager. This was evident from the organizational affiliations of the people chosen, which leant heavily towards an Islamist orientation. One example was a lecturer from a Ma'had in South Jakarta, who has very strong Islamist inclinations. Another one was an activist of one Islamic political party who was also a member of the party for East Jakarta in the regional parliament (DPRD). They are both graduates of universities in Pakistan.

\section{Office mosque stakeholder views of ideological issues}

The section will describe the views held by office mosque stakeholders, consisting of mosque managers, preachers and communities, concerning the ideological issues of the system of government, formalizing sharia law, jihad, gender equality and pluralism. Their views were found by in-depth interviews and informal discussions held by the researchers to ensure the accuracy of the data. These were compiled into a description which can be taken as giving a preliminary picture of the actual ideological orientation of office mosque stakeholders in DKI Jakarta.

\section{System of government: democracy and Islamic caliphate}

In the Muslim world, including Indonesia, there is heated and ongoing debate over which model of government should be implemented in civic and national life. Proponents of radical Islam defend the viewpoint that the best form of government for the followers of Islam should be based on the laws of God, which leads to the concept of striving to establish an Islamic caliphate or an Islamic nation. According to this 
group, in this respect the democratic system is a man-made artifact and its use is not appropriate in the Muslim world, including Indonesia.

Thus, "theological influences" occur when Islam is linked with democracy. On one hand there is the certainty that Islam is divinely revealed by God, making it the perfect, flawless religion, whereas democracy is seen as a human product, making it relative and consequently imperfect. On the other hand, Islam and Islamic culture are seen as being not consistent with democracy. ${ }^{21}$

As the antithesis of the concept of democracy, trust is placed in an Islamic caliphate as the alternative to the various multidimensional crises afflicting Indonesia. Hizbut Tahrir is a group which is trying to resurrect the discourse of establishing an Islamic caliphate, and promoting it as an Islamic system in opposition to the domination of Western democracy. According to Taqiyuddin an-Nabhani, followers of Islam should return to an Islamic caliphate system because it is the only system blessed by God and able to ensure the welfare of humankind. Conversely, all ideologies and faiths outside Islam, such as capitalism, secularism or Judaism, are infidel. ${ }^{22}$

In general, almost every informant interviewed stated their support for establishing an Islamic caliphate, although at the time some informants accepted the practice of the system of democracy. Apart from this, it needs to be noted that those who gave support to establishing a caliphate acknowledged that the idea of an Islamic caliphate was conceptually unclear, and would not be easy to put in place at this time.

Of the three component office mosque groups interviewed, the mosque managers, mosque preachers and mosque members, two of

${ }^{21}$ S. Yunanto, et al, Gerakan Militan Islam di Indonesia dan di Asia Tenggara, Jakarta: the Ridep Institute, 2003, 51-52.

${ }^{22}$ Taqiyuddinn an-Nabhani, Piagam Umat Islam, Bogor: PTI, 2003, 31. 
the members ${ }^{23}$ were noted as strongly stating their support for establishing an Islamic caliphate, although they had little understanding of what an Islamic caliphate would mean. In their opinion the unity of the Islamic community would be more solid if it was under the aegis of Islamic authority, meaning a caliphate. They said that the establishment of an Islamic caliphate, or at least and Islamic state, would hold all the significance of founding a new nation. Their conclusion was that if a caliphate was established, it would bring about insurrection which could harm national unity. ${ }^{24}$

The mosque managers interviewed were uncertain about the mechanism for implementing a caliphate system. They considered that caliphates were the concern and product of times past (long ago), and would be hard to establish today because their structure is not clear. As well as this, in the future the system of authority and who would hold it would become complex problems, as each Islamic nation has its own individual problems. They worried that if the leaders came from another country they would favour their own country, while Indonesia would derive no benefit from this caliphate system. ${ }^{25}$

For mosque preachers, if the Muslim community is well formed the question of establishing a caliphate will resolve itself. One preacher, S.F., appeared reluctant to talk about the caliphate question, and considered that discussion of a caliphate was still a long way off. He thought that the main concern was firstly how to make the people prosperous now. ${ }^{26}$ The preacher A.F. was of the same mind, believing that if the Muslim population is properly composed, a caliphate will come about

\footnotetext{
${ }^{23}$ Interview with SN (43 y.o.), occasional mosque member (employee) and Y (35 tahun), regular mosque member (employee), on 14 July 2010.

${ }^{24}$ Interview with $\mathrm{HP}$, regular mosque member and an employee, on 20 July 2010.

25Interview with AD, Mosque manager, 13 July 2010.

${ }^{26}$ Interview with SF, Mosque preacher, 20 July 2010.
} 
automatically. ${ }^{27}$ K.Y., who is acknowledged as a senior preacher in office mosques throughout Jakarta, also agreed with the concept of a caliphate. However his view was that if people have well developed personal spiritual growth, such as comes through proper family and community life, then individuals will spontaneously want an Islamic caliphate, and it will happen by itself. ${ }^{28}$ So certainly not all the informants interviewed accepted the concept of democracy.

Among the informants interviewed were some who acknowledged that the democracy currently operating in the country was not a problem. According to A.D., today's democracy is good, because it had given people the freedom to engage in politics. ${ }^{29}$ At the same time, for A.F. democracy can be likened to a tool like a knife; what it is used for depends on the person holding it. If it is a good person, it can be used can be used for good, but the converse also applies. According to him, the effects of the democracy now practiced in the nation are being felt already. ${ }^{30}$

However some informants said very firmly that they did not believe in the concept of democracy, and pointed to the practice of democracy as the source of problems in the country. Two full time office mosque teachers blamed the results of democracy for various policies that had not brought benefit to the people. One of them had no faith in the practice of democracy through representatives of the people in parliament. When these two informants took part in elections, they said they supported the Islamist parties that speak out most strongly for the interests of Muslims. ${ }^{31}$

\footnotetext{
${ }^{27}$ Interview with AF, Mosque preacher, 16 August 2010.

${ }^{28}$ Interview with KY, Mosque preacher, 21 August, 2010.

${ }^{29}$ Interview with AD, Mosque manager, 13 July 2010.

${ }^{30}$ Interview with AF, Mosque preacher, 16 August 2010.

${ }^{31}$ Interview with $\mathrm{C}$ and $\mathrm{S}$, office-mosque teachers.
} 


\section{Formalizing Islamic sharia}

In the era of reformation, when the tap of liberalisation has been opened wide, proponents of radical Islam have been very loud in speaking for the idea of formalizing Islamic sharia. This idea has gained momentum since the multi-dimensional national crisis of 1997, which made supporters of Islamic hard-line groups question the existence of the nation state, while turning to the idea of Islamic sharia as a panacea for all the problems and major crises gripping the country. The findings show that to some extent a proportion of the mosque managers accept the idea of formalizing sharia law. Regulating Islamic dress codes is one example of this.

If some informants were still uncertain about the application of an Islamic caliphate or State in Indonesia, almost all informants agreed with the application of sharia law, including its derivatives in the form of Provincial regulations (perda), and forming institutions such as shariabased banks.

The mosque members interviewed said that they fully agreed with putting Islamic sharia into effect in the form of sharia-influenced regulations. According to these informants, it was very fitting for Indonesia, as a nation with a majority Muslim population, to apply sharia law. One person from a different mosque said that he fully supported the introduction of sharia banking. This person even said quite explicitly that he did not feel comfortable working in a conventional bank, and wanted to move immediately to the sharia banking sector. According to him, now that there is a sharia banking system, why do we have to stay with conventional banking which itself contravenes the teachings of the sharia. ${ }^{32}$

\footnotetext{
${ }^{32}$ Interview with $Y$, regular mosque member and an employee, 14 July 2010.
} 
The views of the mosque manager, A.D., and of T.M.A., who runs a women's Islamic study group (TMA), were not far removed from those of the mosque member discussed above. A.D. was adamant that the coming of Provincial sharia regulations was the common aspiration of all Muslims, to create a prosperous, just and peaceful public social order. Further than this, his opinion was that sharia not only made Provincial regulations in written form possible, but that these would truly and tangibly enacted, such that amar ma'ruf nahi munkar, doing good and avoiding evil, would be put into practice according to the wishes of the Muslim people and the teachings of Islam. A.D. went on to say that it would be very good if Provincial sharia regulations were put into force in Jakarta, because its population is extremely diverse. ${ }^{33}$ T.M.A. spoke more about the question of sharia banking, saying that Indonesia has been left far behind by other countries like Malaysia and Singapore. In these two countries sharia banking has developed rapidly and is attracting the interest of many investors, including non-Muslims. He said that Indonesia was one of the pioneers of sharia banking, but its development here was not as fast as in other countries. Watching this made him very concerned about the development of sharia banking in Indonesia. ${ }^{34}$

The views of the mosque preachers about this issue were in accord with those of the stakeholders discussed above, namely that Islamic sharia in the form of provincial regulations must be applied. According to S.F., the Muslim people in fact already enact Islamic sharia in their daily lives, such as the expression of greetings and the way they receive guests. Thus the introduction of Provincial shariah regulations should not cause concern, because these mainly deal with matters of

\footnotetext{
${ }^{33}$ Interview with AD, Mosque manager, 13 July 2010.

${ }^{34}$ Interview with TMA, women's religious study group organiser, 14 July 2010.
} 
moral character. According to him, until now people have had too much of a phobia about the Provincial sharia regulations, and been too narrow minded in their view that sharia will give rise to discrimination against different parties. He further said that the introduction of Provincial shariah regulations would not discriminate against non-Muslims. ${ }^{35}$ At the same time A.D. (the mosque manager) took the view that Provincial sharia regulations presented no threat to non-Muslims, because they really only applied specially to Muslims, and were not binding on non-Muslims. A.D. added that if the regulations promulgated were good, they would certainly be well received. ${ }^{36}$

According to all respondents, it appears that the introduction of Provincial sharia regulations would have a positive impact, because this is part of religious teachings. Everything that comes out of religious teachings and regulation will always have a positive impact on Muslim people, and will not produce any excesses at all, especially for nonMuslims.

\section{Jihad}

In some parts of the West there is a deeply held assumption that Islam is a religion of terror, or one that shows the face of violence and is sustained by the way of jihad. To some extent a similar view is still present in the thinking of Indonesian communities. The perjorative view that Islam takes the jihad route to achieve its religious and political objectives is reinforced by the occurrence of the the September 11 attacks in the US (WTC and the Pentagon), the first and second Bali bombings, suicide bomb explosions in various parts of the world such as in Spain, and more recently the Mujahidin terrorist attacks in Mumbai, India.

\footnotetext{
${ }^{35}$ Interview with SF, Mosque preacher, 20 July 2010.

${ }^{36}$ Interview with AD (Mosque manager), on 13 July 2010.
} 
Informants from each of the three categories (mosque members, mosque managers and mosque preachers) held the view that jihad could be differentially understood as jihad an-nafs or jihad qital, or war. In the case of the war in Palestine, informants (like $Y$ ) would fully agree with initiatives for jihad to help the Palestinians. ${ }^{37}$ S.F. believed that although the true meaning of jihad is war, it had to be re-examined in context. In the Indonesian context it was not correct to see jihad as war, because unlike Palestine, today's Indonesia is not in a state of war. In Palestine people practice jihad by making war because conditions demand it. ${ }^{38}$ A.F. concurred that the Palestinians' choice to wage war was a result of the conditions they experience. However he also said that under normal conditions the meaning of jihad was hard, dedicated work. He added further that jihad as war was justified for self defense, in the way that the Palestinians fight to defend themselves. ${ }^{39}$ In his view self defense is a human characteristic, and this is what Islam proposes. The mosque manager, A.D., saw the meaning of jihad as contributing with body and soul, while war was the last alternative. ${ }^{40}$

On the issue of terrorism, AF did not say definitely whether he agreed or disagreed. He reiterated that it would be better to ask directly to the people that do it. It's quite possible that a teacher of terrorists would adopt a different emphasis. According to A.F., the point is that jihad and terrorism should be meant as ways to defend yourself. ${ }^{41}$

\footnotetext{
${ }^{37}$ Interview with Y, Mosque member, an employee, 14 July 2010.

${ }^{38}$ Interview with SF, Mosque preacher, 20 July 2010.

39Interview with AF, Mosque preacher, 16 August 2010.

${ }^{40}$ Interview with $A D$, Mosque manager, 13 July 2010.

${ }^{41}$ Interview with AF, Mosque preacher, 16 August 2010.
} 


\section{Gender Equality}

These days the struggle for gender equality has been reasonably successful in Indonesia. For example, participation of women in the public sector, open access to education and women's involvement in politics are expanding, and this is a clear indicator of the success of the gender equality agenda. Despite this, the patriarchal culture deeply rooted in Muslim society still presents a number of challenges to the full implementation of gender equality.

In regard to gender equality, some of the informants interviewed stressed that women could not become leaders, especially leaders of the State. For example S.F. said that women could not become State leaders, and that this had already been proven in the time of Megawati who failed as a national leader. He likened the State to a household where most certainly a woman could not become her husband's superior. He went on to say that truly Allah swt. had lightened women's burden so they wouldn't have to seek their own livelihood, because women are already fully occupied by childbearing and household management. ${ }^{42}$ A stronger opinion came from S.N. who said that if a woman became a national leader, then that nation would be destroyed. ${ }^{43}$ This point of view appears similar to the commonly taught doctrine of state leadership, which says that "Allah destroys countries where women become leaders." This doctrine was also much used to reject the previous presidential candidacy of Megawati.

\section{Pluralism}

All informants in the study said that they had no problems in their relations with non-Muslim. However viewpoints like this only represent a

\footnotetext{
${ }^{42}$ Interview with $\mathrm{AF}$, on 16 August 2010.

${ }^{43}$ Interview with SN, occasional mosque member, on 14 July 2010.
} 
relationship of co-existence, a type of relationship which would in fact be accepted by the majority of Muslims and non-Muslims in this country. However there were informants who said that they had no nonMuslim neighbors and seldom interacted with non-Muslims, and thus they had no problems with people of other faiths. ${ }^{44}$

Informant opinions were divided over non-Muslim leadership. According to A.D and T.M.A., having non-Muslim leaders was not an issue for them. It is better to have a non-Muslim leader who brings benefit than a Muslim leader who does not. ${ }^{45}$ T.M.A. recounted his experience at a Bank when it had Muslim and non-Muslim management. He said that the non-Muslim took better care of the employees, was more thoughtful, less penny-pinching, and more concerned for employee welfare. The Muslim was just the opposite. ${ }^{46}$ However they all agreed that other things being equal, the leader should be Muslim.

S.B.N. and $Y$ said that a non-Muslim could not become the Head of State, because the majority of Indonesians are Muslim. A number of these informants appeared to have concerns that if a non-Muslim was leading the country, it would have an effect of the number of nominal Muslims in the country, and end up with discrimination against Muslims. ${ }^{47}$ H.P. said that relations between Muslims and non-Muslims should be on the basis of mutual tolerance, because both had the same rights, however he preferred Muslim leadership. A.F. was of the same opinion, Muslims have a different way of life from non-Muslims, and they should have different leadership. In religious issues there should be links between the way the different faiths are managed, however

${ }^{44}$ Interview with $A D$, mosque manager, on 13 July 2010.

${ }^{45}$ Interview with $A D$, mosque manager, on 13 July 2010.

${ }^{46}$ Interview with TMA, women's religious study group organiser, an employee, on 14 July 2010.

${ }^{47}$ Interview with SN, occasional mosque member, on 14 July 2010. 
for business matters, transactions and other worldly affairs, non-Muslims could be the leaders of Muslims. ${ }^{48}$

The above description of religious teaching practices and office mosque stakeholder perceptions gives the initial picture obtained by the writer, that office mosques to certain degree have become the arena for the growth of Islamic neo-fundamentalism and are strongly influenced by the Tarbiyah movement.

\section{Bibliography}

Azra, Azyumardi, "Islam in Southeast Asia: Tolerance and Radicalism", paper presented at the Mieguyah Public Lecture, the University of Melbourne, Wednesday 6 April, 2005.

Effendi, Bachtiar, "Enforcement of Shari'ah in Indonesia: Challenges and Prospects" in Islam and Democracy, Singapore: KonradAdenauer-Stiftung Singapore, 2004.

Fealy, Greg. Local Jihad: Radical Islam and Terrorism in Indonesia. Australia: ASPI, 2005.

http:www.forsimpta.multiply.com/, last accessed 25 August 2010.

http:www.nu.or.id, last accessed 9 February 2009

Hefner, Robert W., "Political Islam in Southeast Asia: Assessing the Trends" (keynote Address), in conference Political Islam in Southeast Asia, 25 March 2003, Washington DC.

Yunanto, S. et al. Gerakan Militan Islam di Indonesia dan di Asia Tenggara. Jakarta: the Ridep Institute, 2003. an-Nabhani, Taqiyuddinn. Piagam Umat Islam. Bogor: PTI, 2003. 